\title{
Menakar Sayap Politik Perempuan : Studi Garnita Malayahati Partai NasDem Yogyakarta
}

\author{
Bambang Arianto \\ LPPM Universitas Nahdlatul Ulama Yogyakarta \\ ariantobambang@unu-jogja.ac.id
}

\begin{abstract}
This article will explain the political wing of the NasDem women's party namely Garnita Malahayati in Yogyakarta in the 2014 electoral contestation. Various affirmative action policies initiated by the government have not been able to be utilized properly by political parties either in the process of institutionalizing parties to create quality female politicians. Excess, political parties often have difficulty in building awareness of gender mainstreaming and gender-based political education. In fact, the women's political wing of the party has been designed to function to attract women's political participation. The reality is that political parties only make the political wing of women's parties a complement and symbol of politics. This study uses explanatory qualitative methods with data collection techniques by collecting data and related documents and through in-depth interviews. This article argues that there is a dysfunction in women's political wings, because Garnita Malahayati as a political wing of women has not been well institutionalized. The article also believes that the political wing of the party women has not played an active role in the process of candidacy, especially in encouraging the process of regenerating qualified female politicians.
\end{abstract}

Keywords : Women's Politician, Garnita Malahayati, Women's Political Wing

\begin{abstract}
Abstrak
Artikel ini akan menjelaskan sayap politik perempuan partai NasDem yakni Garnita Malahayati Yogyakarta dalam kontestasi elektoral 2014. Berbagai kebijakan affirmative action yang digulirkan oleh pemerintah belum mampu dimanfaatkan dengan baik oleh partai politik baik dalam proses pelembagaan partai untuk menciptakan politisi perempuan yang berkualitas. Eksesnya, partai politik seringkali mengalami kesulitan dalam membangun kesadaran pengarusutamaan gender dan pendidikan politik yang berbasis gender. Padahal, sayap politik perempuan partai telah didesain untuk berfungsi menarik partisipasi politik kaum perempuan. Realitasnya partai politik hanya menjadikan sayap politik perempuan partai sebagai pelengkap dan simbolisasi politik. Penelitian ini menggunakan metode kualitatif eksplanatoris dengan teknik pengumpulan data dengan mengumpulkan data-data
\end{abstract}


dan dokumen yang terkait serta melalui wawancara mendalam (in-depth interview). Artikel ini berpendapat bahwa tengah terjadi disfungsi sayap politik perempuan, dikarenakan Garnita Malahayati sebagai sayap politik perempuan belum terlembagakan dengan baik. Artikel ini juga berpendapat bahwa sayap politik perempuan partai belum berperan aktif dalam proses kandidasi terutama mendorong proses kaderisasi politisi perempuan yang berkualitas.

Kata Kunci : Politisi Perempuan, Garnita Malahayati, Sayap Politik Perempuan

\section{Pendahuluan}

Semenjak ruang demokrasi terbuka lebar di Indonesia pasca Orde Baru, karier politisi perempuan dalam kancah demokrasi dan politik terus mengalami peningkatan yang signifikan. Bahkan sudah banyak aturan penyetaraan gender di tanah air telah menjadikan hak laki-laki dan perempuan diatur secara sama. Terutama affirmative action yang digaungkan oleh Komisi Pemilihan Umum (KPU) menjadi bukti bahwa negara telah membuka ruang publik bagi perempuan untuk berkiprah dalam dunia politik. Hadirnya aturan penyelenggara Pemilu yang memuat aturan penyetaraan partisipasi perempuan dalam kancah politik membuat peran politisi perempuan semakin meningkat. Apalagi, dalam Pasal 55 dan 56 UU Pemilu, menyebutkan, daftar bakal calon yang diajukan partai politik paling sedikit memuat 30 persen keterwakilan perempuan. Kemudian, pada pasal 27 Ayat (1) Huruf b peraturan KPU Nomor 7/2013 menyebutkan, jika ketentuan 30 persen keterwakilan perempuan tidak terpenuhi, partai politik dinyatakan tidak memenuhi syarat pengajuan daftar calon pada daerah pemilihan bersangkutan. Konsekuensinya partai politik bersangkutan tidak bisa ditetapkan sebagai salah satu peserta Pemilu 2014 untuk daerah pemilihan bersangkutan atau tidak bisa mengikuti tahapan daftar calon tetap.

Aturan ini telah menyulut partai politik untuk memenuhi prasyarat Pemilu legislatif, meskipun dalam prakteknya partai politik bergerak setengah hati dalam memenuhi keterwakilan perempuan (Mayrudin, 2017). Sejatinya, partai politik dan perempuan menjadi spasi yang tidak dapat dipisahkan dalam politik tanah air. Hal itu ditandai dengan kehadiran perempuan di panggung politik, yang mulai 
memperlihatkan tren kenaikan. Mengutip studi Manuell Castells (1997) transformasi politik dunia menjelang abad-21, salah satunya ditandai oleh fenomena runtuhnya tatanan patriarki (the end of patriarchy) di berbagai belahan dunia. Keruntuhan patriarki bukan semata-mata dalam pengertian tampilnya perempuan dalam panggung politik guna mengimbangi dominasi kaum laki-laki baik secara kuantitas maupun kapasitas. Tetapi, perubahan fundamental yang lebih mengarah pada formasi sosial politik dan budaya baik dalam ranah privat maupun publik yang menempatkan dominasi kaum laki-laki dalam pembagian peran. Artinya, ranah politik yang selama ini dimaknai sebagai dunia laki-laki, baik dalam aktifitas dan karakter maskulinitas, perlahan telah mengalami transformasi yang tidak saja menempatkan kehadiran kaum perempuan dalam ruang publik, tetapi diiringi oleh tampilnya diskursus feminis dalam arena politik (Hikmawan, 2017).

Ironisnya, keberadaan partai politik seringkali lepas tangan dalam upaya mempromosikan dan memperjuangkan isu-isu pengarusutamaan gender dan perempuan di lembaga legislatif. Sehingga, isu-isu pengarusutamaan gender hanya dijadikan pemanis dalam gelaran kontestasi elektoral 2014. Partai politik akhirnya kembali ke wujud dan karakter asli dengan tetap mengedepankan drama oligarki, patron-klien, dan berbagai kepentingan pragmatis lainnya. Lumrah bila kemudian berbagai hasil survei kontemporer memperlihatkan, keberadaaan perempuan dalam kancah politik belum membawa perubahan yang signifikan (Hikmawan \& Hidayat, 2016). Pemahaman gender sebagai struktur sosial yang meliputi ruang ekonomi, politik dan kebudayaan masih tetap berada dalam naungan struktur patriarki. Kultur politik Indonesia yang patronatif inilah yang membuat publik sangat sulit menerima realitas politisi perempuan dengan pijakan kualitas, integritas dan kapabilitas.

Lemahnya posisi perempuan dalam kultur politik Indonesia juga dipengaruhi oleh belum bekerjanya dan berfungsinya partai politik. Terutama sayap politik perempuan partai yang bertugas mengagregasi kepentingan politik perempuan. Padahal, bila melihat sejarah politik Indonesia, keberadaan sayap politik perempuan partai sejatinya memiliki beberapa fungsi, diantaranya; Pertama, sebagai wahana 
bagi partai politik untuk menyerap, menampung, menyalurkan dan memperjuangkan aspirasi kaum perempuan. Sehingga kaum perempuan yang berada dalam sayap politik perempuan dapat menjadi pekerja politik yang mandiri dan gigih. Kedua, sebagai mesin politik dan aktor intermediari partai politik dalam upaya menarik perhatian dan dukungan elektoral publik. Ketiga, sebagai wahana pembelajaran dan pendidikan politik dalam melahirkan politisi yang berbasis gender. Keempat, fungsi rekrutmen politik dan kaderisasi politisi perempuan dalam menapaki dinamika politik Indonesia.

Alih-alih menjadikan fungsi tersebut sebagai pijakan utama bagi partai politik dalam memberdayakan sayap politik perempuan partai. Ironisnya, justru partai politik hanya menjadikan organisasi sayap partai sebagai pelengkap dan simbolisasi politik. Belum berfungsinya sayap politik perempuan partai secara maksimal akhirnya mengkonfirmasi tengah terjadi disfungsi sayap politik perempuan partai yang menyebabkan minimnya ruang gerak politik kaum perempuan dalam partai politik. Eksesnuya sayap politik perempuan partai seringkali tampak hanya menunggu keputusan elite partai politik yang lebih bercorak oligarkis daripada menjadi organisasi yang mandiri. Ada beberapa faktor yang mempengaruhi minimnya peran sayap politik perempuan partai dalam proses rekrutmen politik yaitu; tipe organisasi partai politik, aturan partai politik, struktur rekrutmen politik, dan tipe kepemimpinan Ketua Umum partai politik.

Artinya, upaya penyemaian nalar pendidikan politik bagi kaum dan politisi perempuan seringkali hanya dijadikan slogan politik tanpa adanya aksi nyata (Syamsuadi \& Yahya, 2018). Sehingga, peran yang diambil sayap politik perempuan partai dalam menyemai gagasan politik kian tidak jelas. Padahal, mengutip studi Joni Lovenduski (2008) bahwa keberadaan lembaga, proses dan prosedur menjadi faktor yang mempengaruhi perubahan jumlah perempuan dalam politik. Bagi kaum feminis, yang bersifat politisi meliputi kehidupan pribadi dan privat (domestik) yang didasarkan oleh hubungan kekuasaan yang tidak seimbang di mana kaum laki-laki mempunyai lebih banyak kekuasan dari kaum permepuan dan juga mempunyai kekuasaan atas perempuan. Dalam hal gender, dapat diperdebatkan 
bahwa lembaga-lembaga politik dapat mencerminkan lembaga-lembaga privat. Studi Izdiha (2017) mengatakan bahwa orientasi perilaku politik perempuan di wilayah Yogyakarta masih kuat dipengaruhi oleh pandangan budaya dan agama yang mereka pahami.

Gejala inilah yang membuat publik meragukan kapabilitas dan integritas politisi perempuan dalam memperjuangkan nasib perempuan dalam konteks politik. Sketsa buram ini dikhawatirkan berdampak negatif bagi masa depan politisi perempuan dalam mengarungi kontestasi politik. Jika merujuk jumlah perempuan yang terpilih menjadi anggota DPR pada periode 2014-2019 tampak terjadi penurunan. Hanya terdapat 88 perempuan atau 15 persen dari jumlah keseluruhan anggota DPR. Jumlah ini turun dibandingkan dengan periode lalu dengan 103 perempuan (18 persen). Padahal penurunan ini tidak sebanding dengan meningkatnya calon tetap perempuan yakni sebesar 37 persen. Realitas ini menegaskan tersendatnya ruang gerak politisi perempuan dalam memperjuangkan nasib perempuan dan pengarusutamaan gender di level parlemen.

Oleh sebab itu, penelitian ini akan mengelaborasi dan menekankan peranan sayap politik perempuan dengan mengambil studi Garnita Malahayati diwilayah Daerah Istimewa Yogyakarta (DIY). Garnita Malahayati berdiri pada 26 Januari 2013, seiring berdirinya Partai NasDem. Granita Malahayati merupakan satusatunya organisasi otonom yang mewadai kader perempuan dalam Partai NasDem. Tujuannya, untuk melakukan penyadaran politik sebagai upaya memperluas keterwakilan politik perempuan dalam melahirkan politisi perempuan yang mengedepankan kapabilitas, integritas dan imparsialitas (Solikhin, 2017).

Pendek kata, besarnya peran sayap politik perempuan partai kemudian mengajak kita pada dua pertanyaan; Bagaimana peran Garnita Malahayati sebagai sayap politik perempuan partai NasDem dalam pemilu 2014? Batasan penelitian ini hanya seputar kebijakan Partai NasDem dalam proses rekrutmen politik para politisi perempuan yang berkorelasi pada peran sayap politik perempuan. 


\section{Kerangka Teori}

Pelembagaan partai politik merupakan salah kunci terpenting bagi masa depan dan kelangsungan partai politik, termasuk dalam pengorganisasian organisasi sayap patai politik. Dengan kata lain, pelembagaan partai politik merujuk pada proses dimana partai politik tertentu mendapatkan nilai baku dan stabil. Sedangkan dimensi pelembagaan partai politik diantaranya meliputi derajat kesisteman, otonomi keputusan, reifikasi dan penanaman nilai dalam masyarakat (Pamungkas, 2011).

Menurut kajian Meny \& Knapp (1998) terdapat tiga ciri pelembagaan partai politik. Pertama, usia organisasi yang tumbuh dan berkembang secara alamiah menurut tahapan waktunya sendiri. Semakin tua organisasi akan semakin terlembaga dengan baik. Kedua, depersonalisasi organisasi. Dalam konteks ini baik kader internal maupun pihak luar sama-sama menyadari dan memberlakukan organisasi yang bersangkutan dengan tidak mencampuradukan dengan kepentingan meskipun kebetulan menjadi pengurus organisasi. Ketiga, diferensiasi organisasional. Dalam konteks ini sejauhmana organisasi berhasil mengorganisasir diri sebagai instrumen untuk memobilisasi dukungan konstituennya. Semakin besar dukungan yang dapat dimobilisasi dan disalurkan aspirasinya melalui suatu partai maka semakin besar pula potensi partai tersebut terlembaga.

Sedangkan pelembagaan partai politik menurut Basedau \& Stroh (2008) menyebutkan ada empat aspek pelembagaan partai politik yakni, Pertama, pengakaran dimasyarakat yang merujuk pada sejauhmana partai memiliki akar yang stabil dalam masyarakat. Kedua, otonomi merujuk pada sejauhmana partai politik bisa independen dari individu dari dalam dan dari luar partai. Ketiga, dimensi organisasi merujuk sejauhmana aparatus organisasi partai dapat hadir konsisten di semua tingkatan administrasi dan bertindak dalam kerangka kepentingan partai. Terakhir, kohesi merujuk pada sejauhmana perilaku partai sebagai sebuah kesatuan organisasi dan sejauhmana tingkat toleransi atas perselisihan dalam partai. 


\section{Metode Penelitian}

Penelitian ini menggunakan metode kualitatif, dengan teknik analisis data eksplanatoris. Teknik pengumpulan data melalui wawancara mendalam (in-depth interview) dengan kader Partai NasDem yakni Aulia Reza Bastian selaku Wakil Ketua Umum Dewan Pimpinan Wilayah (DPW) serta Ketua Badan Pemenangan Pemilu (Bapilu) Partai NasDem DIY. Kemudian, Endang Solawati sebagai Ketua Granita Malahayati Kota Yogyakarta, sekaligus calon anggota legislatif Partai NasDem D.I Yogyakarta pada periode 2014-2019. Selain itu, dalam penelitian ini juga dilakukan pengumpulan data-data yang berasal dari jurnal, berita dari media massa, dan berbagai dokumen terkait dengan penelitian.

\section{Hasil dan Diskusi}

\section{Sejarah Partai NasDem}

Dalam kancah politik Indonesia, Partai NasDem merupakan salah satu partai baru yang dapat lolos tahap verifikasi pada kontestasi elektoral 2014. Partai ini memulai perjalanan sejarah politik dari Organisasi Masyarakat (Ormas) Nasional Demokrat yang kemudian berevolusi menjadi partai politik. Partai NasDem dideklarasikan pada tanggal 25-26 Juli 2011 di Hotel Mercure, Ancol, Jakarta. Deklarasi Partai NasDem hanyalah salah satu tahapan dari satu rangkaian proses panjang perjalanan partai ini. Pendirian lahiran Partai NasDem tidak bisa dipisahkan lepas dari visi dan misi utama organisasi kemasyarakatan (ormas) Nasional Demokrat dalam menggalang Gerakan Perubahan Restorasi Indonesia. Kongres I Partai NasDem pada 25-26 Januari 2013 di Jakarta, akhirnya menetapkan Surya Paloh sebagai Ketua Umum Dewan Pimpinan Pusat (DPP) Partai NasDem periode 2013-2018. Keputusan tersebut diambil pada sidang pleno pertama tanggal 25 Januari 2013 sekitar pukul 23.00 WIB. Ada 33 Dewan Pimpinan Wilayah (DPW), 497 Dewan Pimpinan Daerah (DPD), dan beberapa organisasi sayap partai yang bersatu suara memercayakan Surya Paloh menjadi nakhoda Partai NasDem selama lima tahun. 
Hingga saat ini Partai NasDem memiliki beberapa organisasi sayap partai, yaitu Gerakan Massa Buruh, Liga Mahasiswa NasDem, Badan Avokasi Hukum, Petani NasDem, dan Garanita Malahayati. Meskipun partai baru, Partai NasDem terbukti telah banyak membuat prestasi yang luar biasa sebagai pendatang baru. Melalui, visi dan misi "Restorasi Indonesia", Partai NasDem bercita-cita melakukan gerakan perubahan dalam konteks Indonesia. Dalam kontestasi elektoral 2014, Partai NasDem mendapatkan nomor urut satu (1). Sebagai pendatang baru dan dinyatakan lolos verifikasi untuk mengikuti Pemilu 2014, Partai NasDem berhasil melewati ambang batas Parliamentary Threshold 3,5\%. Secara nasional, Partai NasDem memperoleh 8.402.812 atau 6,72 persen suara, sehingga dapat menempatkan 35 kadernya di DPR RI. Sedangkan untuk wilayah DI Yogyakarta Partai NasDem memperoleh sebanyak 107.432 atau 5,22 persen suara.

Penelitian ini hanya fokus menganalisis Partai NasDem diwilayah DIY yang dimulai dengan menganalisa struktur kepengurusan Partai NasDem DIY dan Granita Malahayati DIY. Dalam struktur kepengurusan Partai NasDem periode 2013-2018 dijelaskan bahwa Ketua Dewan Pertimbangan Wilayah di jabat oleh Dr. Soepomo Prodjoharjono, M.Soc, Sc.Akt. Sedangkan Ketua Dewan pakar oleh Drs. Amin Zakaria, S.E, S.H, M.Si. Ketua Dewan Pimpinan wilayah dijabat oleh H. Subardi, S.H, M.H dengan Sekretaris Suryo Putro Nugroho. Dari 85 kader yang menempati struktur kepengurusan Partai Nasdem periode 2013-208, untuk politisi perempuan hanya 15,3 persen atau 18 politisi perempuan yang memiliki kedudukan dan jabatan di pengurus harian DPW D.I. Yogyakarta.

Adapun posisi kader perempuan hanya diposisi staf biro dan bukan pada posisi strategis. Hanya ada satu kader perempuan yang menduduki anggota Dewan Pertimbangan Wilayah yakni Shinta Kusumaningrum, S.E. Identifikasi ini menjelaskan bahwa sebaran posisi strategis kaum perempuan dalam Partai NasDem belum merata. Hal ini dapat dilihat dari posisi-posisi strategis dalam internal partai masih didominasi oleh kaum laki-laki. Artinya, kuota keterwakilan 30 persen dalam kepengurusan wilayah masih bersifat formalitas dan basa basi politik. Akibatnya, secara substansial peran politisi perempuan masih belum optimal dalam 
kepengurusan Partai NasDem D.I. Yogyakarta. Sedangkan untuk struktur pengurus Garnita Malahayati Partai NasDem DIY, di ketua oleh Sinta Kusumaningrum SE. Dalam kepengurusan Garnita Malahayati DIY dibagi atas beberapa departemen yang kesemuanya di isi oleh kaum perempuan. Selain itu beberapa pengurus inti Garnita Malahayati juga merupakan calon anggota legislatif dalam Pemilu 2014, seperti Sinta Kusumaningrum dan Endang Solawati.

Jika menelaah dari struktur Partai NasDem D.I. Yogyakarta bahwa posisi politisi perempuan belum mendapatkan kuota 30 persen keterwakilan. Padahal, sejatinya dengan dicantumkannya pernyataan tentang kesetaraan gender partai politik harus memastikan bahwa politisi perempuan masuk dalam dewan kepengurusan dan struktur. Hal itu sebagai wujud gambaran sejauh mana partai telah berkomitmen terhadap kesetaraan gender. Dengan dilibatkannya politisi perempuan dalam dewan kepengurusan partai, politisi perempuan dapat juga ikut membentuk kebijakan, prioritas hingga strategis partai. Sebab di beberapa negara, politisi perempuan dan sayap politik perempuan dilibatkan menjadi anggota komisi eksekutif atau yang terkait dengan sumber daya partai, termasuk proses rekrutmen politik. Meski demikian, adanya kuota yang lebih besar dalam kepengurusan sebaiknya diikuti oleh penguatan kapasitas politisi perempuan baik jangka pendek dan jangka panjang termasuk dalam proses pengembangan kapabilitas pribadi. Sehingga, dapat memastikan bahwa perempuan mampu menduduki posisi strategis dalam partai politik.

\section{Ihwal Keterwakilan Perempuan}

Ihwal keterwakilan perempuan jika ditelaah dari Undang-Undang No 8 tahun 2012 telah berupaya untuk membuka selebar-lebarnya kesempatan kepada kader perempuan untuk dapat berpartisipasi lebih aktif dalam dunia politik. Regulasi tersebut telah mendorong partai politik dalam kontestasi elektoral untuk banyak menempatkan kaum perempuan. Sebab Undang-Undang ini memberikan sanksi yang tegas kepada partai politik yang tidak mau memenuhinya. Dampaknya, jika aturan tersebut tidak terpenuhi maka, calon anggota legislatif laki-laki harus 
dikurangi. Artinya, Undang-Undang tersebut sudah cukup tegas dan mendukung kaum perempuan untuk terlibat aktif dalam kancah politik. Sedangkan bagi partai NasDem D.I. Yogyakarta sangat mendukung dan mengapresiasi regulasi soal keterwakilan perempuan, tetapi Partai NasDem D.I Yogyakarta berharap jangan sampai kuota 30 persen keterwakilan perempuan justru membatasi peran perempuan untuk berkiprah dalam dunia politik.

"bahwa penetapan kuota $30 \%$ perempuan dalam UU pada dasarnya dapat disebut sebagai diskriminasi gender. Dengan batasan artinya dapat menutup kesempatan perempuan untuk bisa lebih dari 30\%. Akan lebih baik kuota perempuan sebanyak mungkin atau bahkan lebih dari $30 \% "$

Bagi partai NasDem D.I. Yogyakarta, kesempatan ini harus dapat dimanfaatkan oleh para kader perempuannya. Dikarenakan, Undang-undang No 8 tahun 2012 ini tidak akan ada manfaatnya bila kaum perempuan sendiri tidak mendukungnya. Tetapi realitanya, kendala terberat bagi partai NasDem D.I. Yogyakarta adalah masih banyak kaum perempuan yang masih berfikiran negatif terhadap partai politik, sehingga untuk menarik lebih banyak kaum perempuan menjadi calon anggota legislatif sangat sulit diwujudkan. Itu mengapa, banyak terjadi penolakan dari kaum perempuan ketika ditawari untuk menjadi calon anggota legislatif. Menghadapi hal ini, ada beberapa strategi yang digunakan partai NasDem D.I. Yogyakarta dalam kontestasi elektoral 2014 yaitu;

Pertama, berupaya memenuhi aturan keterwakilan perempuan terlebih dahulu sebagai prasyarat utama untuk menjadi peserta Pemilu 2014. Artinya, untuk tahap awal, Partai NasDem D.I. Yogyakarta lebih mengedepankan aspek kuantitas ketimbang kualitas serta integritas politisi perempuan. Sehingga menjadi wajar bila hasil yang diperoleh dalam kontestasi elektoral 2014, dari lima daerah pemilihan di wilayah Yogyakarta, tidak ada satupun calon anggota legislatif perempuan dari Partai NasDem yang dapat meraup suara terbanyak. Kedua, berusaha memaksimalkan mesin partai politik untuk memperkenalkan kader perempuan kepada masyarakat Yogyakarta. Ada beberapa kegiatan sosial dan keagamaan yang 
digelar oleh partai NasDem. Meski demikian partai NasDem juga mendorong para calon anggota legislatif ini dapat berusaha sendiri secara maksimal untuk memperkenalkan diri kepada masyarakat, bisa melalui jejaring keluarga maupun kekerabatan. Termasuk adanya upaya gotong royong dengan bahu membahu menggandeng para kader perempuan untuk menggaet perhatian masyarakat dengan cara bersama-sama terjun dalam ritual kampanye.

\section{Garnita Malahayati dan Partai NasDem}

Dalam kancah politik lokal untuk periode 2014-2019 Partai NasDem tidak memiliki satu wakil pun di DPRD Daerah Istimewa Yogyakarta (DIY). Tetapi, untuk wilayah DPRD tingkat Kabupaten/Kota di wilayah Yogyakarta, Partai NasDem DIY mampu menempatkan kadernya seperti di DPRD Sleman. Hal itu dikarenakan, Partai NasDem tidak dapat mengevaluasi dari pemilu sebelumnya guna meraih kursi diparlemen lokal terutama di D.I. Yogyakarta. Hal itu disebabkan baru pada tahun 2014 Partai NasDem D.I. Yogyakarta mampu menampilkan calon anggota legislatif, sehingga tidak dapat dikomparasikan dengan hasil dengan Pemilu sebelumnya. Untuk wilayah D.I. Yogyakarta pada tahun 2014 ada lima daerah pemilihan (Dapil), yakni Dapil Yogyakarta 1, dimana ada tiga wakil perempuan. Dapil Yogyakarta 2, ada tiga wakil perempuan, Dapil Yogyakarta 3, ada dua wakil perempuan, Dapil Yogyakarta 4, ada tiga wakil perempuan, dan terakhir Dapil Yogyakarta 5, ada tiga wakil perempuan. Jadi total wakil perempuan Partai NasDem, ada 14 politisi perempuan dalam Pemilu legislatif 2014 silam.

Sebagai pendatang baru, Partai NasDem masih membutuhkan banyak waktu untuk beradaptasi dengan khalayak Yogyakarta. Lagipula, faktor kapabilitas, kompetensi dan integritas para kader partai masih menjadi kendala utama yang dihadapi, termasuk dalam soal rekrutmen politik di legislatif. Dalam proses rekrutmen politik khususnya kaum perempuan, Partai NasDem mengunakan Garnita Malahayati untuk mencari kader perempuan yang memiliki kualitas untuk menjadi anggota legislatif. Tetapi, ada pula pola rekrutmen yang berdasarkan jejaring kekerabatan. Biasanya melalui jejaring ini elite Partai NasDem yang sudah 
mengenal dengan baik figur politisi perempuan tersebut, baik dari modal politik, kultural, ekonomi, dan simbolik. Akhirnya pola-pola yang digunakan dalam proses rekrutmen politisi perempuan tidak lagi mencerminkan aspek inklusifitas maupun eksklusifitas, namun cenderung mengedepankan pola campuran. Artinya, kuota keterwakilan perempuan lebih diutamakan terpenuhi terlebih dahulu, meskipun tidak memiliki kapabilitas sama sekali.

Langkah selanjutnya yang diambil partai NasDem yakni seringkali menggelar rapat koordinasi untuk mengevaluasi tugas dan kinerja para calon anggota legislatif dan legislator perempuan hasil kontestasi Pemilu 2014. Rapat koordinasi yang terjadwal ini untuk melihat sejauh mana capaian kader perempuan tersebut. Apakah telah mampu mencapai target, ataukah sebaliknya. Kemudian juga diupayakan rapat koordinasi ini dapat menemukan kendala-kendala yang dihadapi para politisi perempuan baik yang tidak terpilih maupun yang terpilih menjadi legislator. Dari rapat koordinasi inilah kemudian didapat berbagai keputusan partai. Keputusan ini dapat menjadi rujukan bersama untuk mempertahankan, membina atau mempromosikan politisi perempuan Partai NasDem untuk Pemilu 2019. Meskipun politisi perempuan tersebut berhasil menjadi legislator, namun tidak menjadi jaminan dapat diikutkan kembali dalam kontestasi elektoral 2019 mendatang. Dari rapat koordinasi ini jika ditemui kecenderungan melemahnya kualitas kader perempuan akan segera ditutupi dengan berbagai pelatihan dan sekolah politik diantara;

Pertama, mengadakan berbagai forum grup diskusi (FGD) bagi para politisi perempuan. Tujuannya untuk memberikan bekal pengetahuan dan wacana seputar isu-isu strategis dalam dinamika politik Indonesia. FGD ini juga didampingi oleh pakar dan tim ahli yang sudah dipersiapkan sebelumnya. Ada pula forum diskusi internal secara rutin dengan mengundang berbagai narasumber dari pihak luar seperti Institute of Research Empowerment (IRE) Yogyakarta. Kedua, forum diskusi internal partai yang ditujukan bagi segenap politisi Partai NasDem DIY terutama pegiat Garnita Malahayati. Dalam diskusi ini para kader partai diupayakan untuk dapat mengajukan berbagai pertanyaan seputar masalah yang dihadapi. 
Harapannya, agar para kader partai dapat semakin paham dengan permasalahan yang ada. Forum ini juga digunakan untuk mengawal dan memfasilitasi legislator perempuan terpilih di daerah pemilihannya, sehingga kedepan legislator perempuan ini dapat terus meningkatkan kapabilitas dalam memahami persolaan yang ada dalam masyarakat termasuk alternatif solusinya.

Ketiga, mengelar berbagai forum yang bersifat terbuka dan insidental dengan mengundang masyarakat umum. Forum sosialisasi dan dengar pendapat ditujukan agar dapat mempendek jarak antara partai dan rakyat. Forum sosialisasi ini juga diupayakan untuk mendorong para kader perempuan agar dikenal oleh masyarakat di daerah pemilihannya. Alhasil, forum ini dapat menjadi salah satu sarana pembelajaran dan pendidikan politik kepada masyarakat umum yang digulirkan oleh partai NasDem. Keempat, adanya upaya mendekatkan kader perempuan kepada publik melalui gerakan menulis di media massa lokal. Seruan ini ditujukan agar para politisi perempuan dapat melahirkan gagasan-gagasan cemerlang dan kreatif sebagai upaya mengatasi berbagai problematika kehidupan. Gerakan menulis dengan bekerjasama media massa lokal seperti Harian Kedaulatan Rakyat diharapkan dapat semakin memperkenalkan rekam jejak partai NasDem dan politisi perempuan baik dari sisi kapabilitas, kompetensi gagasan, maupun integritas.

Kelima, dalam upaya mengawal legislator perempuan partai NasDem meluncurkan program "Indonesia Memanggil”. Program ini menggunakan seleksi ketat melalui Fit and proper test yang diberlakukan kepada calon-calon pengurus baru. Harapannya para kader inilah yang di kemudian hari akan dipersiapkan untuk mengisi posisi legislatif maupun eksekutif. Program Indonesia Memanggil bertujuan merevitalisasi kualitas kader dan merekrut kader berkualitas berdasarkan kapabilitas, kompetensi dan integritas. Selama ini kader perempuan yang masuk partai NasDem hanya berdasarkan sukarelawaan semata. Hal itu disebabkan sulitnya mencari kader berkualitas terutama politisi perempuan. Akibatnya pada awalnya Partai NasDem hanya merekrut kader-kader yang berdasarkan jejaring ataupun relasi baik pertemanan maupun keluarga. Tetapi, bukan berarti kader yang direkrut tidak dapat bekerja maksimal. Terbukti beberapa kader-kader perempuan 
partai NasDem juga mampu menarik simpul-simpul massa yang otomatis dapat memperbaiki citra partai.

Dalam konteks rekrutmen dan kaderisasi politisi perempuan, peranan Garnita Malahayati memiliki peran yang signifikan. Garnita Malahayati bertugas menarik kaum perempuan untuk ikut berpolitik sekaligus memperbaiki kualitas para calon anggota legislatif perempuan maupun legislator perempuan terpilih yang diusung partai NasDem. Artinya, kebijakan yang diambil oleh partai NasDem secara otomatis dapat bersinergi dan berkesinambungan dengan program-program Garnita Malahayati. Meski demikian, Garnita Malahayati bersifat sebagai lembaga mandiri, sedangkan untuk persoalan bantuan keuangan dan operasional organisasi masih didukung oleh partai NasDem. Relasi partai NasDem dengan politik perempuan tentulah tidak lepas dari peran sayap politik perempuan maupun departemen perempuan. Garnita Malahayati merupakan rumah bersama gerakan perempuan partai NasDem yang menghimpun dan membangun solidaritas sesama perempuan secara lintas golongan, tanpa diskriminasi atas dasar apapun. Garnita Malahayati menolak segala bentuk kekerasan dan ketidak-adilan gender yang mengatasnamakan agama dan atau keyakinan, adat istiadat, dan ideologi tertentu.

Hingga saat ini Garnita Malahayati D.I Yogyakarta telah memiliki dan sedang membuka beberapa jejaring dengan organisasi perempuan dan gerakan masyarakat sipil lainnya. Tujuannya untuk dapat berbagi informasi soal upaya pengarusutamaan gender. Selain itu ada pula kerjasama dalam berbagai pelatihan agar para pegiat Garnita Malahayati memiliki keterampilan sebagai pekerja politik sekaligus komitmen pada isu-isu politik perempuan. Meski demikian ada beberapa kendala yang dihadapi Garnita Malahayati dalam mengarungi dinamika politik Indonesia. Pertama, masih minimnya kesadaran dan sulitnya mencari kader perempuan untuk menjadi pengurus Garnita Malahayati. Sehingga pengurus Garnita Malahayati sangat sulit mencari sosok dan figur yang berkualitas untuk mengarungi dinamika politik. Padahal kunci sebuah organisasi dapat berjalan dengan maksimal adalah pada faktor model kepemimpinan. Kedua, minimnya dana operasional keuangan yang diberikan oleh partai yang seringkali membuat kerja- 
kerja teritorial Granita Malahayati kurang begitu maksimal. Bahkan, selama ini berbagai kegiatan hanya bersifat spontanitas dan sukarelawan politik dari para anggota partai.

Meski demikian, hal itu tidak menyurutkan aktivitas sayap politik perempuan dalam mengagregasi kepentingan masyarakat. Dalam pemberdayaan masyarakat Garnita Malahayati dapat menggelar berbagai macam pelatihan yang tidak sebatas dalam konteks politik. Tetapi juga meliputi isu-isu sosial seperti bidang kewirausahaan. Dalam konteks advokasi sosial, Garnita Malahayati cukup memuaskan, bahkan pernah melakukan aksi sosial yang ingin menggugat Komisi Pemilihan Umum seputar adanya upaya akal-akalan kebijakan affirmative action.

Sedangkan untuk dinamika di aras lokal, keberadaan Garnita Malahayati kurang begitu berdaya. Hal itu disebabkan sulitnya mengajak perempuan untuk aktif terjun dalam kancah politik.. Alhasil, upaya transfer pendidikan politik kepada yang dilakukan Garnita Malahayati seperti pelatihan dan pendidikan politik belum berjalan maksimal. Selain itu, sayap politik perempuan partai hanya hadir dan bergerak menjelang kontestasi elektoral saja. Sehingga menyebabkan masyarakat terutama kaum perempuan seringkali tidak begitu mengenal sayap politik perempuan partai NasDem. Selain itu dengan hadirnya fenomena relawan politik (Arianto, 2015) membuat banyak kaum perempuan lebih tertarik bergabung dalam berbagai organisasi sukarelawan politik ketimbang sayap perempuan dibawah naungan partai politik.

\section{Kiprah Politisi Perempuan Partai NasDem}

Dengan dibukanya saluran politik serta adanya tuntutan pengarusutamaan gender bagi perempuan di parlemen, telah memberikan dampak peningkatan jumlah perempuan yang terlibat dalam politik. Dalam level yang lebih luas, seperti pada periode 2004-2009 keterwakilan perempuan di DPR menunjukkan grafik yang mengembirakan. Dari 11,8 persen pada 2004 kemudian meningkat lagi menjadi 18,05 persen pada 2009. Angka itu jauh lebih tinggi daripada hasil Pemilu 1955 yang hanya menempatkan 17 perempuan (6,25 persen) terpilih dari 272 anggota DPR. Hal 
yang sama juga terjadi di level DPRD provinsi, keterwakilan perempuan di parlemen pada 2004 hanya 10\% persen, tetapi meningkat menjadi 15 persen pada 2009. Sedangkan, untuk level DPRD kabupaten/kota mengalami peningkatan dari 18 persen pada 2004 menjadi 27 persen pada 2009. Selain itu, pada kontestasi elektoral 2004, ada sekitar 2.507 (33 persen) bakal calon anggota legislatif dari perempuan yang mengisi daftar calon anggota legislatif, dan kemudian meningkat menjadi 3.910 (34,7 persen) bakal calon anggota legislatif di Pemilu 2009. Ironisnya, meningkatnya partisipasi kaum perempuan dalam kontestasi elektoral 2014, ternyata belum didukung oleh sistem pencalonan internal partai yang adil dan merata seperti dalam penentuan nomor urut.

Padahal, peraturan KPU No 7/2013 dengan terang menjelaskan bahwa pencalonan anggota DPR, DPRD provinsi/kabupaten kota telah mensyaratakan bahwa penempatan calon legistlatif perempuan di nomor urut teratas. Tetapi realitanya tidak sedikit partai yang berdalih bahwa sistem pemilihan dengan suara terbanyak tidak akan mempengaruhi nomor urut. Pada Pemilu 2009, misalnya, ada 44 persen calon legislative perempuan DPR RI yang terpilih menempati nomor urut satu (1) ada sekitar 29 persen, terpilih dari nomor urut dua (2) ada sekitar 20 persen, terpilih dari nomor urut tiga (3) ada sekitar 7 persen. Artinya, penempatan nomor urut secara psikologis juga dapat mempengaruhi tingkat perilaku memilih publik.

Bila dilihat peta persebaran perempuan dalam internal partai NasDem, memang belum memenuhi kuota 30 persen. Artinya, dominasi kepemimpinan patriarki masih menjadi halangan utama kaum perempuan dalam kancah politik. Meskipun secara aturan affirmative action untuk 30 persen pengurus telah terpenuhi. Tetapi dari sisi kapasitas dan kekuatan politisi perempuan di partai NasDem belum terlihat. Hal ini dapat dilihat dari perolehan kursi di parlemen. Secara umum anggota legislatif perempuan partai NasDem di DPR RI hanya berjumlah 4 orang dari 35 anggota legislatif yang ada. Sedangkan untuk wilayah D.I Yogyakarta, partai NasDem belum dapat menempatkan kader perempuan.

Terlepas dari persoalan kapabilitas personal politisi perempuan, secara umum memang isu-isu yang ditawarkan oleh calon anggota legislatif perempuan 
partai NasDem telah memperhatikan permasalahan perempuan, seperti perdagangan perempuan, perdagangan anak, kekerasan dalam rumah tangga (KDRT) dan masalah tenaga kerja. Calon anggota legislatif partai NasDem pada dasarnya telah berupaya membangun wacana untuk perbaikan untuk permasalahan gender. Meski demikian calon anggota legislatif perempuan tersebut belum mampu meyakinkan masyarakat karena ketatnya persaingan. Hal ini sebagai konsekuensi dari minimnya kuantitas kader. Selain itu, ada pula persoalan nonteknis lainnya seperti kecemburuan diantara sesama politisi perempuan, bergantung pada kekuatan suami atau keturunan keluarga dan jejaring patron-klien yang menyebabkan kekuatan politisi perempuan tersebut kurang dominan.

Hal itu mengkonfirmasi bahwa, usaha dan kerja pemenangan yang dilakukan partai NasDem masih bersifat normatif. Meski demikian, tetap ada upaya memberikan bantuan untuk mensosialisasikan caleg dengan melakukan programprogram sosialisai pada pemilu 2014 yang lalu seperti pengajian, kegiatan bazar dan kegiatan lainnya. Dalam pemilihan legislatif 2014, belum ditemui upaya dan strategi khusus dan fokus untuk memenangkan caleg perempuan dalam kontestasi elektoral 2014. Hal itu dibenarkan oleh Aulia Reza Bastian, bahwa partai Nasdem D.I Yogyakarta dalam pemilu 2014 lebih fokus dalam upaya pemenuhan kuota 30 persen caleg perempuan. Pasalnya, sebagai partai baru, untuk mencari 30 persen saja, partai NasDem harus bekerja ekstra keras. Sehingga dalam geraknya para elite partai tidak jarang berusaha me"NasDem"kan seseorang yang telah bersedia menjadi caleg Partai NasDem sambil berjalan. Bahkan, hampir semua calon perempuan untuk pemilu legislatif sangat sedikit memiliki interaksi dengan partai politik.

Jika ditelaah ada beberapa faktor yang mempengaruhi tingkat keterpilihan beberapa legislator perempuan partai NasDem tingkat kabupaten di wilayah D.I Yogyakarta, diantara (1) Tingkat kedikkenalan (elektabilitas) di masyarakat yang cukup tinggi. (2) Memiliki jejaring kekerabatan yang cukup luas seperti garis keturunan (trah) serta telah menjadi publik figur (modal simbolik). (3) Memiliki modal ekonomi sehingga mampu bergerak secara mandiri. Identifikasi tersebut 
mengambarkan bahwa kendala terberat yang dihadapi kaum perempuan adalah pola-pola kultural yang masih berlaku di masyarakat, konsep patriarki yang membuat perempuan di nomor duakan baik dalam urusan politik, ekonomi, sosial dan budaya. Sehingga gerak langkah politisi perempuan dibatasi dengan sejumlah cara, mulai dari aturan partai politik dan kehidupan parlemen yang maskulin. Dengan kata lain, meskipun perempuan dilibatkan dalam pemilu 2014, akan tetapi dipaksa ikut dalam aturan politisi laki-laki. Hal ini menyebabkan partisipasi perempuan yang masih setengah hati dalam berpolitik (Azmy AS, 2014).

\section{Revitalisasi Sayap Politik Perempuan}

Dalam perkembanganya ada beberapa tantangan yang dihadapi legislator perempuan dalam parlemen diantaraya; Pertama, tantangan diskursus atau ideologis yang mana masih buramnya ideologi yang menjadi panutan para legislator perempuan. Terutama dalam soal ideologi yang berbasis gender. Alhasil, gerak langkah para legislator perempuan cenderung mengikuti jejak kaum patriarki bahkan hingga harus ikut dalam habitus korupsi suap. Kedua, hambatan sosioekonomi yang menegaskan bila para legislator perempuan tidak semua memiliki modal sosial dan ekonomi seperti yang dimiliki oleh kaum laki-laki.

Alhasil, hambatan ini dapat mempengaruhi tingkat kedikkenalan politisi perempuan di hadapan masyarakat. Beragamnya latar belakang yang dimiliki oleh seorang legislator perempuan menjadi penyebab terjadinya perbedaan dalam memahami berbagai persoalan. Sebut saja, seorang legislator perempuan yang memiliki latar belakang bidang ekonomi kemudian ditempatkan dalam komisi di parlemen yang tidak linier dengan bidang ilmunya. Maka, legislator perempuan ini akan membutuhkan banyak waktu untuk beradaptasi dalam komisi tersebut. Apalagi, dengan minimnya wakil Partai NasDem di parlemen terutama di DPRD menyebabkan para legislator perempuan mau tidak mau menerima komisi apapun.

Ketiga, hambatan politisi dan kelembagaan. Hal ini dapat dicerna dari masih dominannya kaum patriarki dalam setiap pengambilan keputusan dan kebijakan partai. Apalagi, dalam konteks partai NasDem D.I Yogyakarta wakil perempuan di 
pengurus harian hanya 15,3 persen. Selain itu posisi Garnita Malahayati bukan sebagai lembaga penentu kebijakan dan keputusan partai. Jika, Garnita Malahayati memiliki kekuatan yang mutlak atau setidaknya dapat mempengaruhi keputusan partai, secara tidak langsung dapat meningkatkan posisi para kader dan kelembagaan legislator perempuan baik dipartai maupun diparlemen. Keempat, hambatan pribadi dan psikologi yang menunjukan realitas patriarki di tingkat individu dan masyarakat seringkali menjadi kendala utama bagi kaum perempuan untuk terlibat aktif dalam kancah politik.

Dengan begitu, banyak kader perempuan akhirnya mengurungkan niatnya untuk terjun ke kancah politik karena tidak disetujui oleh keluarganya. Seperti enggan untuk mendaftar menjadi calon legislatif. Selain itu adanya stigma kotornya dunia politik dan tidak setimpalnya pengorbanan keluarga yang harus diberikan kaum perempuan dalam berpolitik menjadi alasan utama sebelum terjun menjadi pekerja politik. Lagipula, adanya paradigma demostifikasi sebagai kodrat perempuan yang selalu dirumah, menjadi salah satu penyebab melebarnya kesenjangan antara kaum perempuan dan dunia politik

Dalam konteks partai NasDem D.I Yogyakarta, para politisi perempuan tetap diupayakan menjadi politisi perempuan yang berkualitas dan responsif terhadap problematika publik. Caranya dengan merevitalisasi kualitas personal, melalui program "Indonesia Memanggil". Program ini lebih bertujuan merevitalisasi kualitas kader dan merekrut kader-kader berkualitas berdasarkan kapabilitas, kompetensi dan integritas. Meskipun, ada masa reses untuk turun ke daerah pemilihan dan mendengar masukan konstituen, tetapi para kader perempuan partai NasDem D.I. Yogyakarta harus tetap kritis dengan persoalan yang dihadapi masyarakat. Isi gagasan bisa membahas soal apapun yang terkait dengan problematika masyarakat, baik seputar pasar tradisional, pendidikan, agama soal kesehatan dan sebagainya. Harapannya, dengan semakin banyak politisi perempuan yang aktif memperjuangkan keadilan gender dengan maju menjadi calon anggota legislatif dapat menjadi pertanda perkembangan partisipasi kader perempuan dari sekadar memenuhi kuota atau representasi menuju peran politik perempuan yang 
lebih berpengaruh dalam hidup bernegara kita. Akan tetapi kendala yang dihadapi para legislator perempuan, dapat menjadi wahana berperannya, Kaukus Perempuan Parlemen untuk merevitalisasi kualitas para legislator perempuan di parlemen.

Identifikasi tersebut menegaskan bahwa rendahnya perolehan suara politisi perempuan Partai NasDem D.I Yogyakarta, sangat terkait dengan belum maksimalnya fungsi Garnita Malahayati sebagai mesin politik kaum perempuan dalam kontestasi elektoral 2014. Padahal, peran sayap politik perempuan partai sejatinya berkontribusi pada pengembangan kebijakan, mendorong kepentingan perempuan dalam platform kebijakan dan memberikan saran kepada pimpinan partai tentang isu gender; berkontribusi dan mengawasi pelaksanaan. kebijakan kesetaraan gender, mengkoordinasikan kegiatan anggota perempuan di dalam partai; menjalankan fungsi sosialisasi dan mobilisasi terutama untuk menjangkau pemilih perempuan semasa pemilihan dan memperluas basis partai; berkontribusi pada pembentukan hubungan kekuasaan di dalam partai dan memberikan pemahaman dan pelatihan kepada anggota partai tentang kesetaraan gender.

Di beberapa negara revitalisasi sayap politik perempuan partai telah dapat menjadi alternatif untuk mendorong partai politik melaksanakan reformasi serta meningkatkan partisipasi perempuan. Oleh sebab itu tentu sayap politik perempuan partai dapat disinergiskan kedalam struktur partai, dengan peran dan tanggung jawab yang jelas, termasuk persoalan pendanaan untuk biaya operasional. Meski demikian, sayap politik perempuan partai harus berhati-hati agar isu gender tidak menjadi pemicu terbelahnya politisi perempuan dalam sebuah partai. Jika semua partai politik memiliki agenda yang sama yakni berupaya merevitalisasi sayap politik perempuan, hal itu dapat meningkatkan keterwakilan perempaun dalam politik termasuk meningkatkan kuantitas jumlah legislator perempuan di parlemen.

\section{Kesimpulan}

Data tersebut menegaskan bahwa Garnita Malahayati belum dapat berfungsi secara maksimal dalam memberikan kesadaran atas pengarusutamaan gender. Artinya, posisi Garnita Malahayati selama ini hanya dijadikan sebagai organisasi 
pelengkap dan hanya bertugas menjadi organisasi "pengumpul suara" dari kaum perempuan semata. Jika, hal ini terus merebak, maka dapat dipastikan, mekanisme rekrutmen politik serta proses kaderisasi partai akan dirusak oleh figur yang memiliki popularitas semua namun miskin elektablitas (Soetjipto \& Adelina, 2012).

Gejala disfungsi ruang gerak Garnita Malahayati harus segera diatasi oleh partai NasDem dengan merevitalisasi peran sayap politik perempuan partai sebagai organisasi yang mandiri, sekaligus memberikan dukungan yang maksimal kepada sayap politik perempuan partai baik, materiil maupun imateriil. Garnita Malahayati sebagai sayap politik perempuan partai harus diberikan kewenangan dalam menentukan keputusan partai, serta diikutkan sertakan dalam proses rekrutmen politik. Hal ini ditujukan agar fungsi dan peran sayap politik perempuan partai dapat berjalan secara maksimal.

Dengan begitu Garnita Malahayati, akan dapat mengefektifkan komunikasi kepada para kaum perempuan dalam upaya mewujudkan isu pengarusutamaan dan kesetaraan gender menuju terwujudnya partai politik modern. Terakhir, Garnita Malahayati sebagai sayap politik perempuan partai harus dapat memastikan penguatan kapasitas dan memperluas jejaring advokasi guna meningkatkan kesadaran berpolitik bagi kaum perempuan, sehingga dapat mendorong keterwakilan perempuan yang lebih luas.

\section{Referensi}

Afifuddin, Muhammad (2012). Feminisme Korupsi. Republika, Edisi 15 Februari.

Antaranews.com.(2014)http:/ / www.antaranews.com/berita/431082/pdip-pimpinperolehan-suara-di-diy

Arianto, Bambang. (2014). Fenomena Relawan Politik Dalam Kontestasi Presidensial 2014. Jurnal Ilmu Sosial dan Ilmu Politik. Vol. 18,No. 2 Edisi November.

Azmy, Ana Sabhana. (2014). Kajian Khusus Feminimitas dan Maskulitas Politik Perempuan : Telaah terhadap Representasi Anggota Deewan Perempua di Komisi III dan IX DPR RI Periode 2009 - 2014. Jurnal Politika. Akbar Tanjung Institute. Volume 10 No.1 
Bppm.jogjaprov.go.id.2014)PembentukanKaukusPerempuanParlemen.(Online)http://w ww.bppm.jogjaprov.go.id/index.php?option=com_content\&view $=$ article\&id $=130$ :pembentukan-kaukus-perempuan-parlemen-sediy\&catid=31\&Itemid=54, diakses 18 Juli 2015.

Caton, Matthias (2007). Effective Party Assitance : Stringer Parties for Better Democracy, IDEA, Sweden.

Castells, Manuell. (1997). The Power of Identity. London and New York. Blackwell Publishing

Field, Bonnie N., dan Peter M Siavelis, (2008). Candidate Selction Prosedure in Transitional Polities, A Research Note, Party Politics. Sage Publicaiton. Los Angeles.

Hazan, Reuven Y., Gideon Rahat. (2001). Candidate Selection Methods : An Analytical Framework, Party Politics. Vol. 7 No. 3. SagePublication. Los Angeles.

Hemas, GKR. (2013). Perempuan dalam Ujian. Kompas edisi 7 Juni.

Hikmawan, M. D. (2017). Pluralisme Demokrasi Politik di Indonesia. Journal of Governance, 2(2), 223-247.

https://doi.org/http:// dx.doi.org/10.31506/jog.v2i2.2678

Hikmawan, M. D., \& Hidayat, R. (2016). Depoliticisation of Public Issue : Low

Degree of Government ' S Democratic Legitimacy. Journal of Governance, 1(1), 23-37. https://doi.org/http:// dx.doi.org/10.31506/jog.v1i1.1311

Kpu.or.id. (2014). Data Caleg dan Anggota Legislatif Perempuan. (Online). www.kpu.or.id, diakses 28 Juni 2015

Kpud-diyprov.go.id. (2014) http://kpud-diyprov.go.id/main.php?hal=DC, diakses 30 Juni 2015.

Kompas.co. (2014) Survei: Perempuan Masih Dipandang Sebelah Mata di Dunia Politik Indonesia.(Online).http://nasional.kompas.com/read/2014/02/11/2159058/S urvei.Perempuan.Masih.Dipandang.Sebelah.Mata.di.Dunia.Politik.Indonesia, diakses 25 Juni 2015.

Lovenduski, Joni. (2008). Politik Berparas Prempuan. Kanisius. Yogyakarta

Mayrudin, Y. M. (2017). Dinamika Partai Politik Dan Positioning Ideologi: Studi

Tentang Pergeseran Positioning Ideologi Partai-Partai Politik Peserta Pemilu

2014. Journal of Governance, 2(2), 163-185.

https:// doi.org/10.31506/jog.v2i2.2674

Mietzner, Marcus. (2013). Money, Power and Ideology, political Parties in PostAuthoritarian Indonesia. Singapura. National University of Singapore Press

Norris, Pippa, Joni Lovenduski. (1195) Political Recruitment; Gander, Race and Class in the British Parliament. Cambridge Up. Cambridge.

Pamungkas, Sigit. (2011). Partai Politik Teori dan Praktik di Indonesia. Institute 
Democracy and Welfarism. Yogyakarta

Puskapolui.ac.id. (2013).Keterwakilan politik perempuan di tingkat lokal. (Online) http://www.puskapol.ui.ac.id/publikasi_puskapol/hasil-riset-keterwakilanpolitik-perempuan-di-tingkat-lokal.html, diakses 28 Juni 2015.

Puskapolui.ac.id. (2014) AnalisisPerolehan Suara dalam Pemilu2014:Oligarki Politik dibalik KeterpilihanCaleg Perempuan. (Online) http://www.puskapol.ui.ac.id/publikasi_puskapol/analisis-perolehansuara-dalam-pemilu-2014-oligarki-politik-dibalik-keterpilihan-calegperempuan.html, diakses 29 Juni 2015.

Partainasdem.org.(2014).ProfilPartaiNasdem.(Online) https:// www.partainasdem.org/sejarah, diakses 25 Juni 2015.

Rumahpemilu.org. (2014). Basa Basi Keterwakilan Perempuan. (Online) http:/ / www.rumahpemilu.org/in/read/1849/Basa-Basi-KeterwakilanPerempuan-oleh-Bambang-Arianto, diakses 28 Juni 2015.

Soetjipto \& Adelina, 2012. Partai Politik dan Strategi Gender Separuh Hati. Pelajaran dari Pengalaman Tiga Partai Pemenang Pemilu 2009. Jakarta. Parentesis Publisher.

Solikhin, A. (2017). Menimbang Pentingnya Desentralisasi Partai Politik di Indonesia. Journal of Governance, 2(1), 36-64.

https:// doi.org/10.31506/jog.v2i1.2120

Syamsuadi, A., \& Yahya, M. R. (2018). Model Kandidasi Birokrat Oleh Partai

Politik Pada Pemilihan Kepala Daerah Langsung Di Kabupaten Rokan Hilir

Tahun 2015. Journal of Governance, 3(2), 133-153.

https://doi.org/10.31506/jog.v3i2.3868

Struktur Kepengurusan Partai NasDem DIY, SK DPP Partai Nasdem No : 129SK/DPP- NasDem/III/ 2013

Tribunnews.com.(2012). Granita Malahayati Nasdem Niat Demo KPU. (Online). http://www.tribunnews.com/nasional/2012/09/07/garnita-malahayatinasdem-niat-demo-kpu, diakses 27 Juni 2015.

Tempo.co.(2013).RatuAtutdiTahan.(Online).http:/ / nasional.tempo.co/read/news/20 13/12/20/063539030/Ratu-Atut-Ditahan, diakses 25 Juni 2015.

Thejakartapost. (2014) Women's political representation. (Online) http:/ /www.thejakartapost.com/news/2014/01/27/women-s-politicalrepresentation-prepare-2019.html\#sthash.qkhv5Jxj.dpuf, diakses 30 juni 2015.

Yves Meny and Andrew Knapp. (1998). Government and Politics in Western Europe: Britain, France, Italy, Germany, third edition. Oxford University Press.

Wawancara Aulia Reza Bastian, Ketua Bappilu Partai Nasdem DIY 2014

Wawancara Ir. Endang Solawati, M.P, Sekretaris I DPD Partai Nasdem Kota Yogyakarta dan Ketua Garnita Malahayati Nasdem Kota Yogyakarta 